\title{
Plants and foods as identity markers: an ethnographic analysis on the case of the (Y)Ezidis from Batman (Turkey)
}

\author{
Berivan Can Emmez(D)
}

\begin{abstract}
Located in the geographical region called Upper Mesopotamia, Batman has a wide cultural diversity. One of the Kurdish (Kurmancî)-speaking ethno-religious communities of Batman is the (Y)Ezidis which have been subjected to several persecutions due to their syncretic belief and practices. The resistance of the Ezidis against imperial powers could be read from governmental manuscripts kept in the archives. The number of field researches conducted in the area of Ezidis in Turkey is quite low. These studies are also concentrated in Viransehir (Urfa) region in which the Ezidi population is more intense. This study, on the other hand, is uncovering the traditional plants which are being used for food and nutrition as well as healing and ritualistic practices by the Ezidis of Batman which has never been subjected in a research in anthropology. Nutrition as one of the necessities that must be met in order to maintain biological existence is also a cultural phenomenon. Food as a part of culture is a configuration of identity and self-expression. The aim of this study is uncovering the traditional plants which are being used for food and nutrition as well as healing and ritualistic practices by the Ezidis of Batman which has never been subjected in a research in anthropology. The primary data of this study was collected during an ethnographic fieldwork in between April 2013 and June 2015 in Ezidi villages of Batman. It was observed that Ezidis unite with the other communities of the region with nutritional methods based on animal products which are common in daily life, while they differ in the use of plants and cereals which are operated in ritual practices. The ritualistic uses of plants and foods and the relations of the Ezidis between the others over food are proposed in this study as the basic patterns of behavior that distinguish Ezidi community from others, define belonging, and mark ethnic identity.
\end{abstract}

Keywords: Ethnobotany, Identity, Ezidi, Batman (Turkey), Darê kenêre, Pelor, Gûriz, Rêvaz, Sîrim, Xerdel

\section{Introduction}

Batman is located in the geographical region called Upper Mesopotamia which is regarded as one of the first settlements in human history (Fig. 1). Due to its location in the geography of ancient civilizations, it has a wide cultural diversity. One of the Kurdish (Kurmancî)-speaking ethno-religious communities of Batman is the (Y)Ezidis. They live mainly in the South-Eastern provinces of Turkey, such as Midyat (Mardin), Viranşehir (Urfa), and Beşiri (Batman). (Y)Ezidis of Turkey regard this region which is called Zozan or Xaltan as their homeland.

Historically, due to their syncretic belief and practices, Ezidis have been subjected to several persecutions, which

Correspondence: berivancan@gmail.com

Faculty of Arts and Sciences, Batman University, 72100 Batman, Turkey they called ferman. For instance, the resistance of the Ezidis against Ottoman power could be seen from many sources like Evliya Çelebi's Seyahatname or other governmental manuscripts kept in the archives. More recently, in 2014, hundreds of Ezidis were killed and forced to flee to the holy Mount Sinjar and neighboring countries or faced to conversion or slaughtered by the Islamic State (Daesh/Isis). By the way, most of the Ezidis fled European countries via Turkey after the IS massacre. This memory of persecutions plays a unifyingassociating role against an external threat and makes them emphasize their identity as a reaction. Besides, the religious doctrines which determine social belonging such as faith in being chosen and the lineage that does not allow exogamy, penetrate into all spheres of the

(C) The Author(s). 2020 Open Access This article is distributed under the terms of the Creative Commons Attribution 4.0 International License (http://creativecommons.org/licenses/by/4.0/), which permits unrestricted use, distribution, and reproduction in any medium, provided you give appropriate credit to the original author(s) and the source, provide a link to the Creative Commons license, and indicate if changes were made. The Creative Commons Public Domain Dedication waiver (http://creativecommons.org/publicdomain/zero/1.0/) applies to the data made available in this article, unless otherwise stated. 


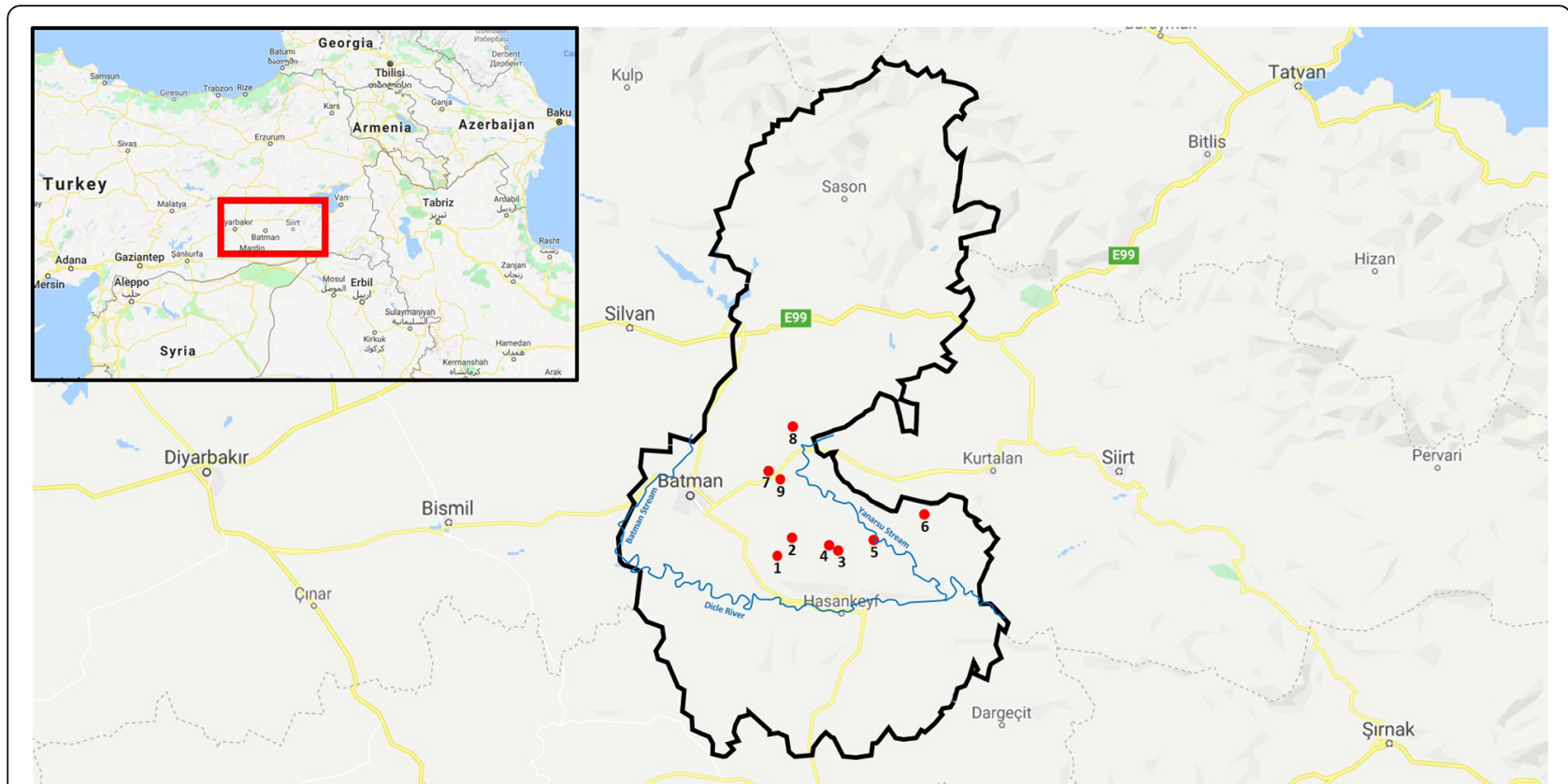

Fig. 1 Area of the study: Map showing Batman province at the South-East of Turkey and the studied settlements with numbers. Village 1 , Yolveren (Çinêra); 2, Üçkuyular (Feqîra); 3, Oğuz (Şimsê); 4, Onbaşı (Şahsim); 5, Kumgeçit (Bazîvan); 6, Kurukavak (Hamdûna); 7, Uğrak (Taharî); 8, Uğurca (Qorixê); and 9, Beşiri district. The Ezidis, one of the Kurdish (Kurmancî)-speaking ethno-religious communities of Batman live in these villages

culture. Therefore, Ezidism requires to be defined as an ethno-religion and ethno-culture.

It should be stated that since not only the most important figure of the religion, Peacock Angel (Tawusî Melek), is recognized as a representation of Satan by the Abrahamic religions so they gained notoriety as the Devil worshippers but also the commonly known name Yezidi/Yazidi evokes the Islamic caliphate Yazid bin Muawiyah; its members in Batman province show an insistence about naming themselves as Ezidis. Furthermore, the word Ezidi is written as $\hat{E} z \hat{\imath} d \hat{\imath}$ in Kurdish (Kurmancî), and the initial vowel is pronounced like /i/. In this context, it is going to be mentioned as Ezidis in this article.

The leading study mentioning the Ezidis living on the North of the region recognized as Batman today is Layard's great work Nineveh and its Remains, which has also attracted the attention of Western orientalists by making them known as devil worshipers [22]. The fountain built by the grandson J. Guest in memory of Layard in Kurukavak (Hamdûna) (Fig. 2), a mostly abandoned village of Batman today which is located on a hill surrounded by barren lands, has been preserved for many years despite it being useless at present. Until most recent studies of Turkish researchers-such as Okçu [25], Süvari [26], Adsay [1], and Gökçen [16], not only focusing essentially on the history, religion, music, and/or culture of the Ezidis but also including restricted information on Ezidis of Batman-there is not even a source providing data on Ezidis of Batman. Moreover, the only ethnobotanical study determining traditional knowledge of Ezidis (and Kurds) on food was held in Armenia [17]. This study which stems on an ethnographic fieldwork focuses on the connections between food and identity in the context of Ezidis, an ethno-religious community, living in Batman (Turkey). The lack of previous scientific studies on food and plants of the Ezidis of Batman makes the study significant.

Culture has a unifying and binding structure both in social and temporal dimensions. It connects the people who construct society by providing the opportunity for trust and support with its unifying and binding power via the symbolic world of meaning consisting of spaces of common experience, expectation, and action [5]. It is this state of cultural continuity known as tradition which provides political imagery (identity) on the other side. Food as a part of culture is a configuration of identity and self-expression. This study aims to compile the traditional knowledge based on the foods and plants used by the Ezidis of Batman and to analyze the relationship between nutrition and identity of an ethnic group. 


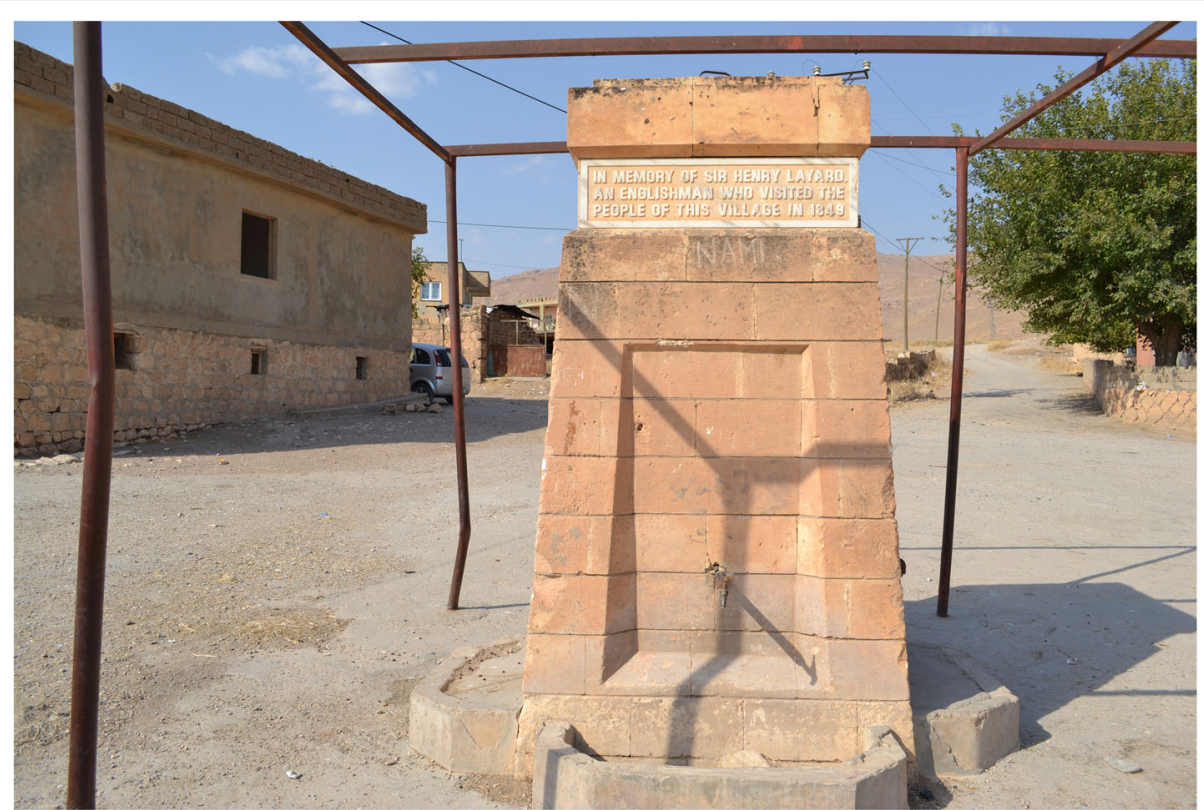

Fig. 2 Layard's Fountain: The fountain built by the grandson J. Guest in memory of Archeologist Austen Henry Layard who has the leading study mentioning the Ezidis living in Kurukavak (Hamdûna), a village recognized within Batman today, has been preserved for many years and reached today despite it being waterless. It is quite ironic that the meaning of the name Kurukavak is arid poplar tree (Populus)

\section{Materials and method}

Unfortunately, the Ezidis of Turkey had experienced another persecution away from their holyland Laleş, under the conflict between the Kurdish movement and the Turkish regime in the 90s. Even though the majority of the population has migrated to European countries due to the negative socio-economic effects of the conflict, especially to Germany, a smaller number of Ezidis continued to live in their homeland. After the IS attack, Ezidis from Iraq and Syria settled in Ezidi villages which had been abandoned by the Ezidis of Batman as well as the refugee camp in Uğurca (Qorixê) village in Beşiri (Batman/Turkey) district (Fig. 3). However, this study does not investigate among Ezidi migrants from Iraq and Syria. The primary data of this study was collected during a fieldwork in between April 2013 and June 2015. For an ethnographic research on verbal culture of the Ezidis based on participant observation [8], remaining Ezidi villages, which are Uğurca (Qorixê), Uğrak (Taharî), Kurukavak (Hamdûna), Kumgeçit (Bazîvan), Üçkuyular (Feqîra), Yolveren (Çinêra), Oğuz (Şimsê), Onbaşı (Şahsim), and Beşiri district of Batman were studied.

Audio-visual instruments were used in this study, only with the consent of the informants, in order to support the researcher's memory. For the sake of security, the names of the informants were systematically encoded, in which the initials of the informants are utilized with the initial of social castes $[20,21]$ (sed $\hat{u}$ had) which are $\mathrm{M}$ for murid, $\mathrm{P}$ for pir and $\mathrm{S}$ for $s \quad x$. In other words, the characters before the initials represent the social caste which the informant belongs. Unfortunately, neither feqîr nor qewwal exists in Batman.

According to the approaches to human nutrition as a biological action, human metabolism refers to the process of meeting the nutrient and energy needs. However, the provision of nutrients necessary for the supply of energy, making it suitable for human consumption, and the process of consumption behaviors not only make nutrition a biological activity, but also transform it into a cultural phenomenon [7]. That is in fact what makes food to be also defined as "embodied material culture" [10]. Food, as a part of cultural practices which equips the individual with a social environment, is a significant indicator of the identity of individuals. Food not only nourishes but also signifies the social forces that the individuals are constructed by. As Fischler pointed out [14], human beings mark their membership of a culture or a group by asserting the specificity of what they eat or more precisely by defining the otherness, the difference of others.

Ethnographic method, which is a term that expresses writing about people and culture, has an important role in cultural anthropology. This importance stems from the idea that understanding the perspective of the researched community can only be achieved through 


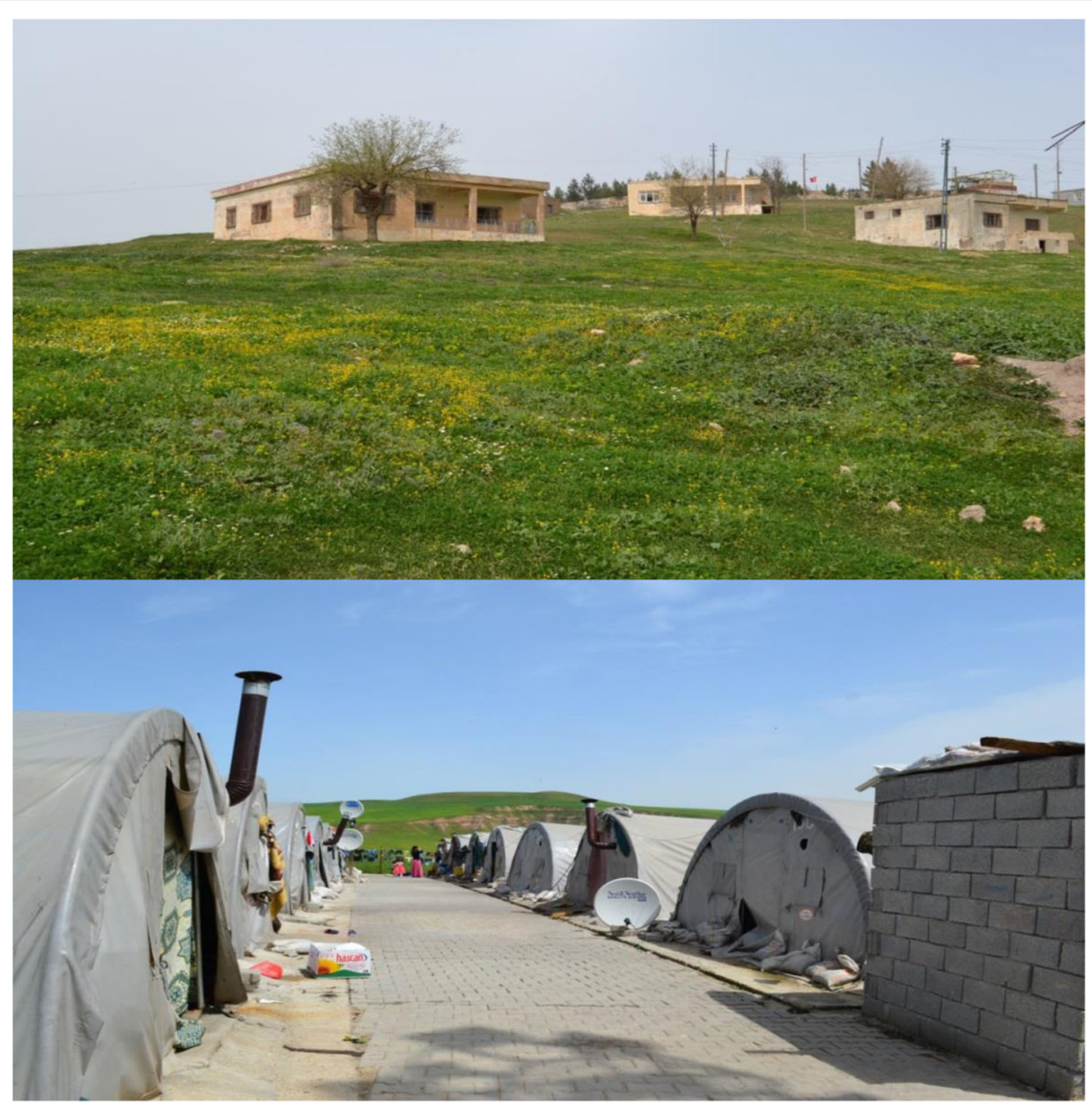

Fig. 3 Settlements of the Ezidis from Syria and Iraq in Batman: Although only twenty five Ezidi families remained due to negative socio-economic effects of the conflict between Kurdish movement and the Turkish regime, the population of the Ezidis in Batman reached thousands after the mass migration from the neighboring countries in 2015. The figure above shows the abandoned houses of Ezidis in Oğuz (Şimsê) village (April 4, 2013). Tents from the refugee camp in Uğurca (Qorixê) village (April 16, 2015) which are settled by the Ezidis from Syria and Iraq appears below

participation [3]. Participating observation may vary from regular commuting to the community where the researcher examines from his or her living space to being fully involved in community life [6]. The researcher, who has been involved in the daily life of the community for a long time, observes, asks questions, and experiences being a member of the community. Participant observation is the main method of understanding the perspective of the native. Data obtained through firsthand observations are described and carefully recorded. In this respect, ethnographic activity constitutes a large repository of information on culture.

On the other hand, it is necessary to go beyond description and to interpret the data collected from the field and other sources of information. According to the hermeneutic approach, which is a concept proposed by the humanities as an alternative for the positivist approach, human existence is determined by culture, which is the network of meaning surrounding it [15].
Revealing this network of meaning that determines human actions is only possible with an insight view. In other words, the way to obtain accurate information about the society is to be one of those by experiencing and observing.

Anderson [4] mentions that food is used to mark and symbolize matters of communion and theology. He argues that religious foodways are not blind immemorial tradition but pragmatic adaptations to community life and so could be explained on the basis of religious and ritual logic as well as ecological sense. In this context, this study regards nutrition practices as a cultural phenomenon. The provision, production, and consumption processes were observed by participation and discussed under an Anthropological point of view. Cultural, religious, and sociological connections were hypothesized. Overall, the study gave a contribution for both cultural and botanical studies in terms of revealing the connections between nutrition and culture by recording 
the data about the healing practices of plants and traditional foods and analyzing the effects of religious identity and discourse over food.

Most of the studies on Ezidis and Ezidism have been carried out among Ezidis living in Armenia, Iraq, and Syria and in European countries. The number of field researches conducted in the area of Ezidis in Turkey is quite low. These studies are also concentrated in Viransehir (Urfa) region in which the Ezidi population is more intense. The aim of this study is uncovering the traditional plants which are being used for food and nutrition as well as healing and ritualistic practices by the Ezidis of Batman which has never been subjected in a research in anthropology. By the way, it has to be kept in mind that the local names of the plants should be considered since this study stems basically on ethnographic method although the names in Latin are mostly stated via referring the related literature. It has to be indicated that botanical studies need to be held in this field.

Another issue to be clarified is the names of the villages. Settlement names were changed by the commissions established under the Ministry of Interior in the Republican period because they were not Turkish; however, the old names of the settlements [2] remained in social memory as in the case of Batman. In this study, local names that are still in use are given in parenthesis along with the official names.

\section{Results and discussion}

Cultivation of cereals such as wheat, barley, lentils and corn constitutes the primary occupation for family needs of Ezidis in Batman whereas sheep breeding still remains as highly demanded. As a result of a common belief among the Kurdish Muslims on eating animal meat (gosst) breeded by the Ezidis would be haram (forbidden for the ones who are Muslim), Kurdish (Muslim) shepherds are employed by Ezidi families. Even so, a significant majority of Kurdish Muslims could be observed refusing to eat in Ezidi houses.

It should be pointed out that there are various conceptions in relation with Ezidis and food which could also be followed via the literature on Ezidis. The travel literature for example, written in the early modern period is full of many examples that point to the fact that food is a powerful marker of culture used both to define and differentiate [11]. Evliya Çelebi, for instance, tells in his work Seyahatname that "when the Satan set foot on the earth from heaven, garlic (sîr) appeared from his left foot, onion (pivaz) appeared from his right foot. Therefore the Ezidis always carry onion and garlic in their pockets. The one shows the courage to mash the onion will immediately be killed by the Ezidis" [13].

Furthermore, there are significant taboos on eating several plants especially on cabbage (lehane), lettuce (xas), and sea fish (masî). As most of the scholars mentioned before, the taboo on cabbages and lettuce are told to come from an oral tradition about the Ezidi prophets, Sheikh Adi and Sheikh Hasan [20, 21]. According to this tradition, a cabbage drew aside from the prophet and did not let him hide. Another tradition signifying the lettuce and cabbage had been thrown to Sheikh Hasan, an Ezidi sacred man, has been seen as the possible the reason of the taboo. It was also told by the Ezidis of Batman that eating sea fish is also forbidden because prophet Yunus had been ingested by a fish. ${ }^{1}$ Neither cabbage nor lettuce was observed to be eaten; however, I was informed that the taboo on these plants was not widespread since it is only for religious castes such as pir and $s, x$, but freshwater fish occurred to be prepared as dinner during the research. Yet the implementation of taboos seems to be varying according to the region [17].

Although the aim of this study is not completely providing information about the Ezidi religion, some doctrines which directly determine the culture of food will be adverted. The sacred earth-sky pair, depicted as the wife and husband of each other, is one of the prominent elements in Ezidism as in various mythologies. The earth and the sky are considered as the sister and brother in sacred hymns, emphasizing that the sky gives life to the earth with rainfall. The sky sows its seeds with water which is the predecessor of each form, to the ground. On the other hand, the faith of the earth is to give birth. In the context of fertility, earth gains value especially in the agricultural cycle [12]. The God's (Xwed or $E z d a)$ transcendence and creative power are revealed with rain by the sky; blessings are distributed to the earth by rain.

In addition, it could be stated that religious discourse gives a form to human experiences as a reproduction area of tradition. The Ezidis celebrate the first Wednesday of April of the Julian calendar as Çarşema Sor in which life sprinkled on the earth with the rain of the sky is conceived as the marriage of the sky and the earth. Ezidis believe that this sacred marriage has taken place in April so that they call the month as "the bride of the year" and do not practice weddings in this month ${ }^{2}$. Papaver [18], a red flower which begins to appear gener-

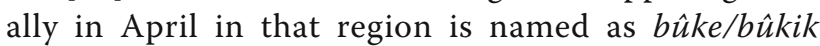
which means bride in Kurdish (Kurmancî) (Fig. 4). The flower is generally used by children in their

\footnotetext{
${ }^{1}$ Information provided by MS, in Kumgeçit (Bazîvan) on July 19, 2014. ${ }^{2}$ This information was provided by MK in Onbaşı (Şahsim) on August 1, 2013.
} 


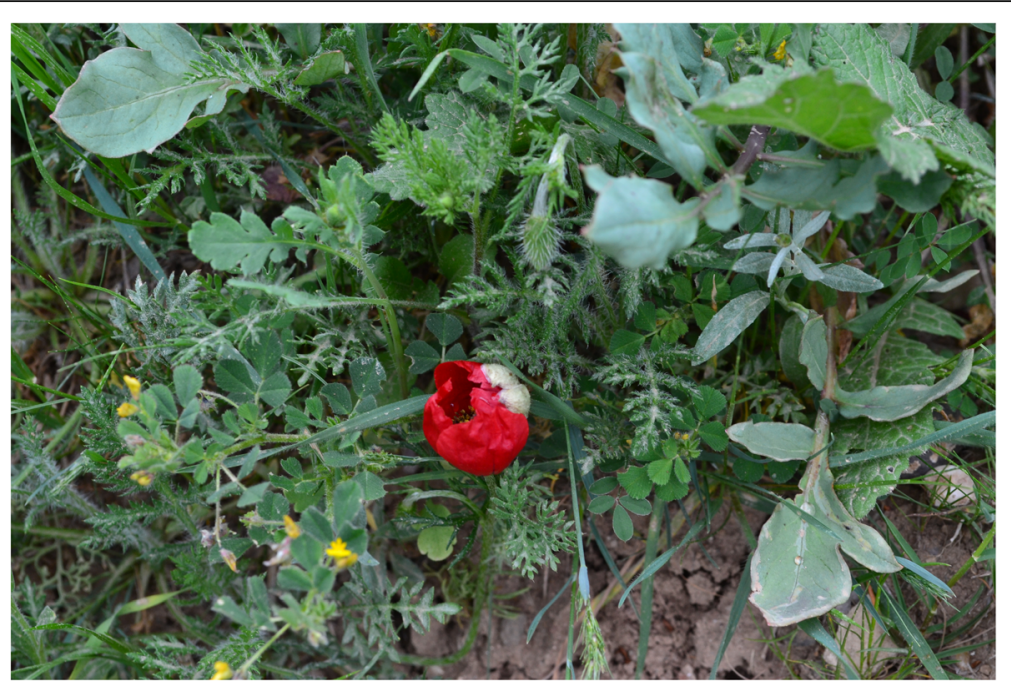

Fig. 4 Bûkik, the bride: Yolveren (Çinêra) village April 17, 2013. The red flower which begins to appear generally in April in that region is named as bukke/bûkik which means bride in Kurdish (Kurmancî). In the context of the sacred sky-earth pair as an archetype for human behavior, Ezidis believe that April is the bride of the year. They celebrate the first Wednesday of April of the Julian calendar as Çarşema Sor in which life sprinkled on the earth with the rain of the sky is conceived as the marriage of the sky and the earth

games, to make a bride by folding the petals down or to dye their cheeks and nails with its bright red color. Colorful eggs symbolizing eternal fertility of the earth giving birth to every creature on it are served for the children and the quests with chocolate and candies.
Four days after the feast, entwisted amulets in sacred colors (red, yellow, and green or red and white), known as basimbar which is used for protecting from bad luck and getting blessings, are hanged on crops at the fields, door of the houses, or vehicles (Fig. 5). Ezidis also discern a foreigner is an Ezidi whether she/he carries a

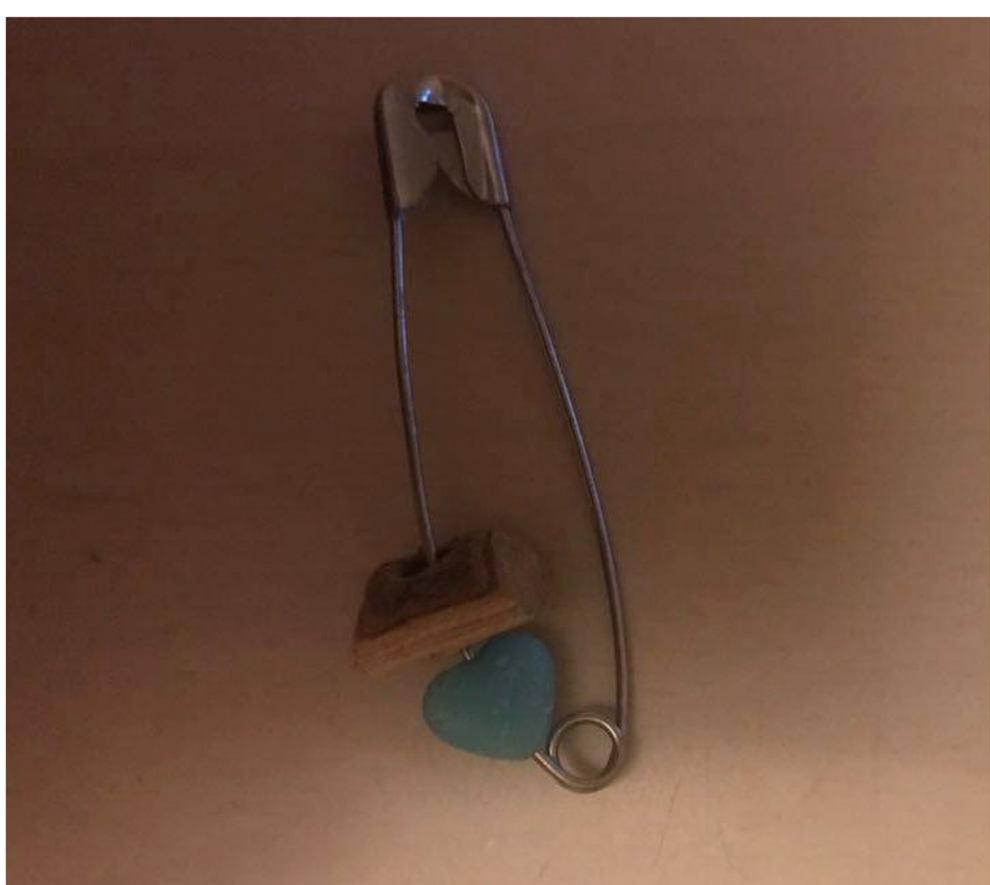

Fig. 5 Darê Kenêre: Made of prunus mahalep attached to a needle with a blue bead, believed to get rid of evil eye. Oğuz (Şims ) village, May 16,2014 
basimbar either on the wrist, ankle, or neck (Fig. 6). Another amulet which is called Darê kenêre made of prunus mahalep and believed to get rid of evil eye. It is used to be attached to the clothes via a needle with a blue bead or evil eye (Fig. 7).

As it was mentioned above, nature is an important component in Ezidism. Most of the Ezidi sacred places identified with white domes that are called a "qub" which includes sacred trees and/or plants too that are used to be believed to bring evil for the one who attempts to cut or damage it (Fig. 8). ${ }^{3}$

The earth obtained from these sacred places or from the tombs of holy figures (Fig. 9) is also used as teberik which means healing via the sacred earth by dissolving it in water or lumping and taking through the mouth or nose. Teberik heals specific diseases according to the attribute(s) of the holy person.

All Ezidis have to carry the sacred earth pellets called berat (Fig. 10) which is brought from the temple of Sheikh Adi in Lalesh. During the funeral practices, berat had to be put in the mouth and eyes of the dead. The Ezidis of Batman mention that they have experienced some difficulties about carrying berat abroad, especially on the borders. The lack of information on the pellets constantly causes confusion among the officials and makes the Ezidis feel culpable and deficient.

Another considerable feast in the context of fertility and blessing is celebrated on the 19th of February. Two holy brothers, Xidir and Îlyas, are believed to meet on that day every year. At the end of the 3 days fast in which animal products are forbidden to ingest, a pudding-like mush called pelor is prepared with various types of cereals: corn, barley, wheat, lentils, chickpeas, rice, and walnuts. Initially, the cereals are roasted before grinding in a stone muller. Then, three cups of the cereal and walnuts mixture are boiled with half-liter water for $10 \mathrm{~min}$. After the mixture turns into a mush, it is transferred into a plate. If preferred, it is formed into a round shape with a hollow in the middle. Finally, some molten butter (nivîşk) and dems (boiled grape or mulberry juice) is poured on the mush (Fig. 11). A piece of the mush is wrapped in a cloth and put under the pillow at night after making a wish which is believed to come true in the following days. Feeding the animals with pelor and sprinkling it to the fields indicates its role in the belief on sharing of food and distribution of fertility. ${ }^{4}$

It had been observed that the most preferred products in daily life among Ezidis in Batman consists of

\footnotetext{
${ }^{3}$ Information derived from MF on February 1, 2014, in Kumgeçit (Bazîvan) and MS on September 29, 2013, in Oğuz (Şimsê). ${ }^{4}$ Information provided by PS on 18 February in Üçkuyular (Feqîra), 2013, and MN on 19 February 2014 in Onbaşı (Şahsim).
}

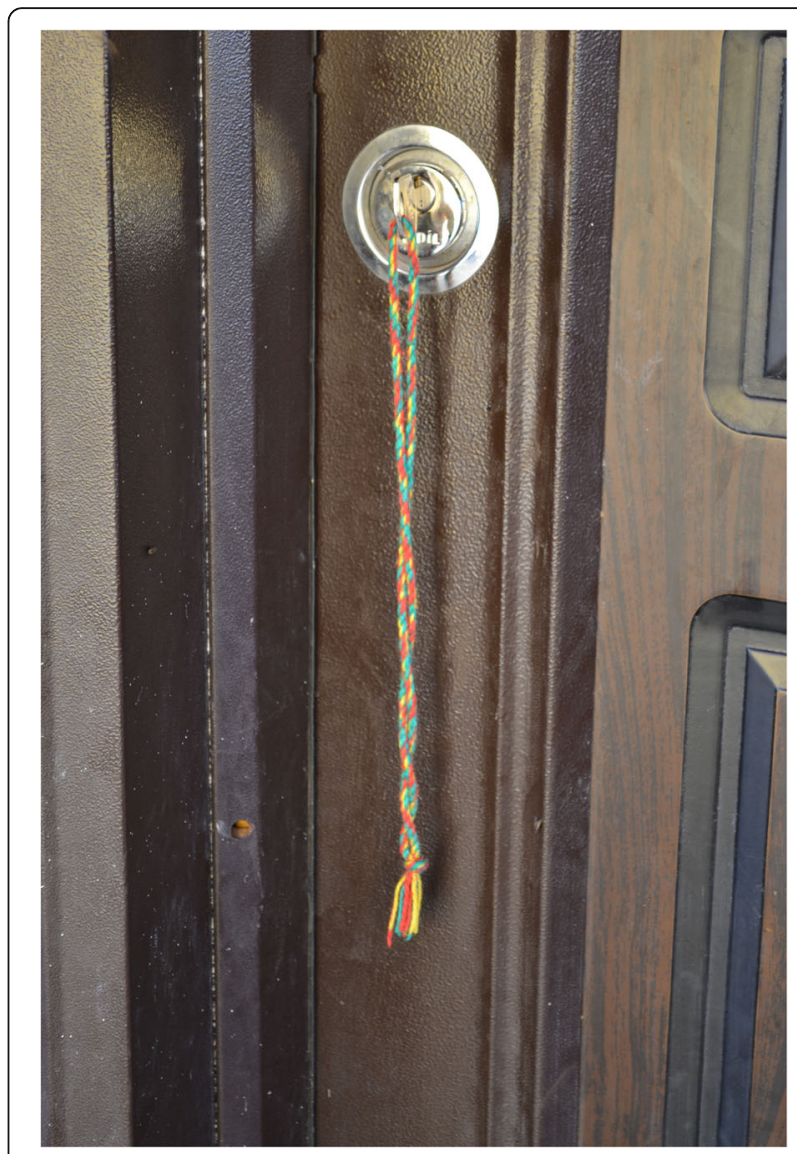

Fig. 6 Basimbar: the sacred amulet entwisted 4 days after Çarşema Sor, hanging on the door of an Ezidi house. Üçkuyular (Feqîra) village, July 5, 2013

meat (preferably lamb, more often chicken, rarely turkey), bulgur (sawar), and milk products such as yoghurt (mast) and cheese (pen r), resembling elevated dishes of Kurdish Muslims of the region (Fig. 12). The majority of traditional dishes prepared using plants are based on cereals, such as dry beans and chickpeas with meat and bulgur pilaf.

Plants such as cucumber, tomato, qitî (Cucumis flexuosus) [23], onion, parsley, watermelon, melon, grape, apple, and peach are cultivated in the large courtyards or gardens of the houses. Moreover, it is possible to come across a pistachio and/or a mulberry tree in the yards of all houses. The other plant products are mostly edible wild plants gathered from nature (çol ) such as kereng (Gundelia tournefortii [19]), gûriz (Anchusa azurea [19]), rêvaz (Rheum ribes [19, 24]), sîrim (Allium schoenoprasum [9]/Allium scorodoprasum L. [19]), and xerdel (Sinapis arvensis [19]), which are used as combinations with animal products such as egg and cereals. 


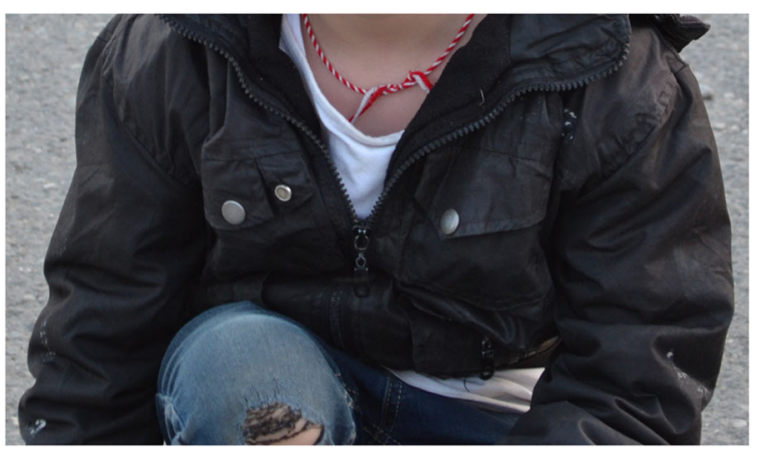

Fig. 7 Ezidi Boy with Basimbar: Oğuz (Şims ) village, May 31, 2015. Ezidi boy with basimbar on his neck. Ezidis could be identified with these knitted amulets on them. The amulet should not be removed unless it rubs off otherwise it is believed to cause bad luck

Sirim, a kind of garlic, is a highly preferred wild plant used in bulgur pilaf (Fig. 13) and in cheese. Rêvaz is favorable to eat fresh whereas kereng is edible as raw or cooked. On the other hand, gûriz and xerdel can be eaten after cooking. Gûriz is hard to wash and clean due to its spiny leaves (Fig. 14). It ought to be drained after boiling in salty water then transferred to a buttered pan for cooking with some eggs.

\section{Conclusion}

As it was tried to be demonstrated in this study, food is directly related with Ezidi culture, lifestyle, and religious identity. Volition in the means of self-representation and identification and differentiation with the other communities in the social context becomes clear over food. Ezidism, by codifying foods in a cultural way, attributes sacredness by shaping the food culture of individuals through these meanings. In addition, it makes

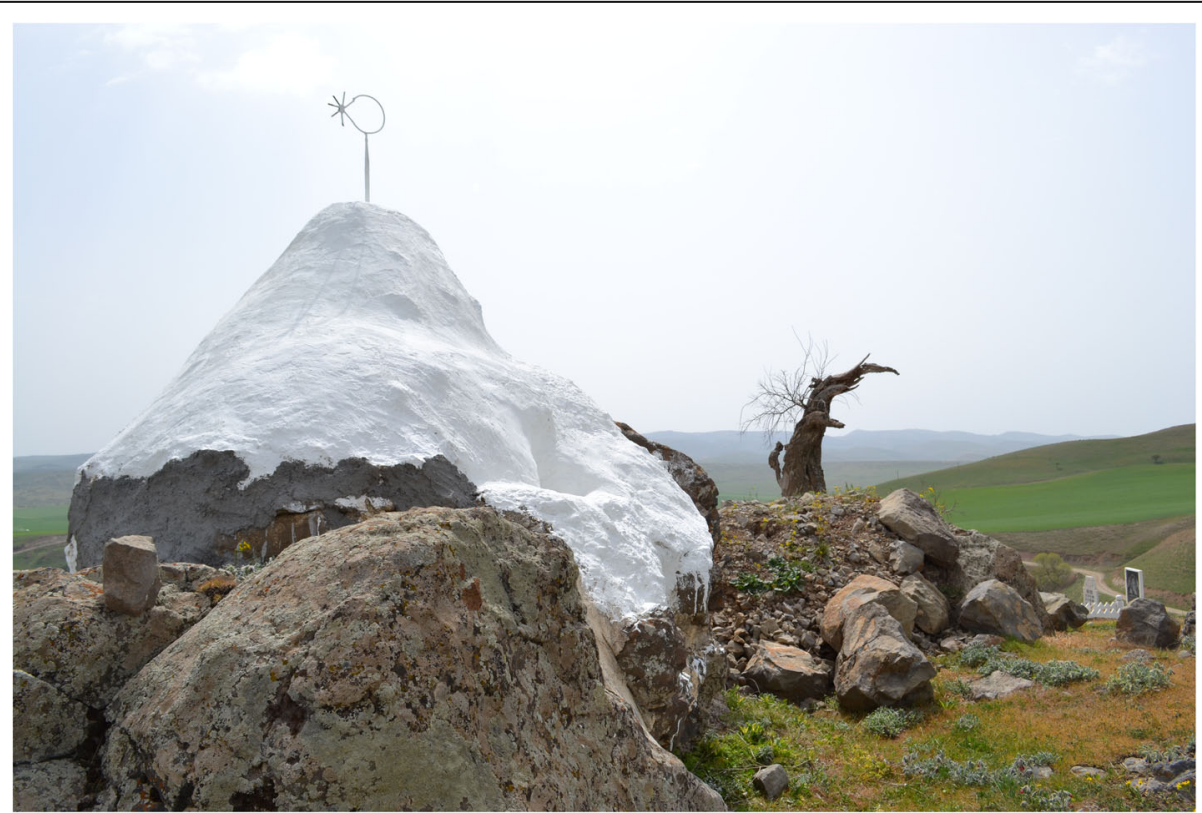

Fig. 8 Qub'il Dor (Dome of Cycle): Oğuz (Şims ) village, April 4, 2013. A sacred Ezidi place called Qub'il Dor (Dome of Cycle) near with a sacred tree on which has a taboo against damaging it. This place is also a cemetery situated on the top of a hill. The symbol of the moon and the sun on the dome points to the conception of cyclical time. The Ezidi sacred places and cemeteries on the high hills expressing metaphysical unification under the sun and moon, mark a point where the dead and the living worlds link together 


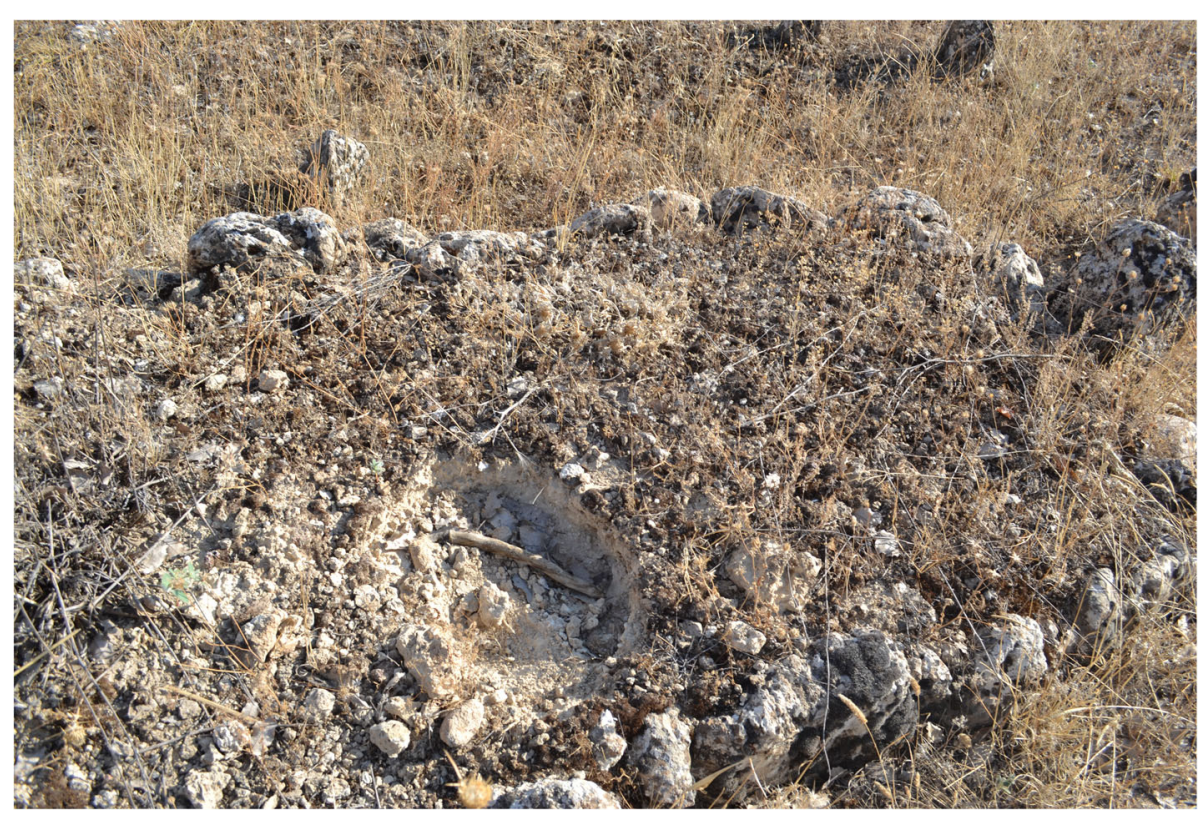

Fig. 9 Teberik: There are several tombs of holy figures in Ezidi cemeteries. The earth obtained on the tombs of holy figures is used for healing which is called teberik. Teberik heals specific diseases according to the attribute of the holy person. For instance, teberik made with the earth on this grave was being used for healing hepatitis since the holy woman had the attribute to cure hepatitis when she was alive. Kumgeçit (Bazivan) village, August 13, 2014

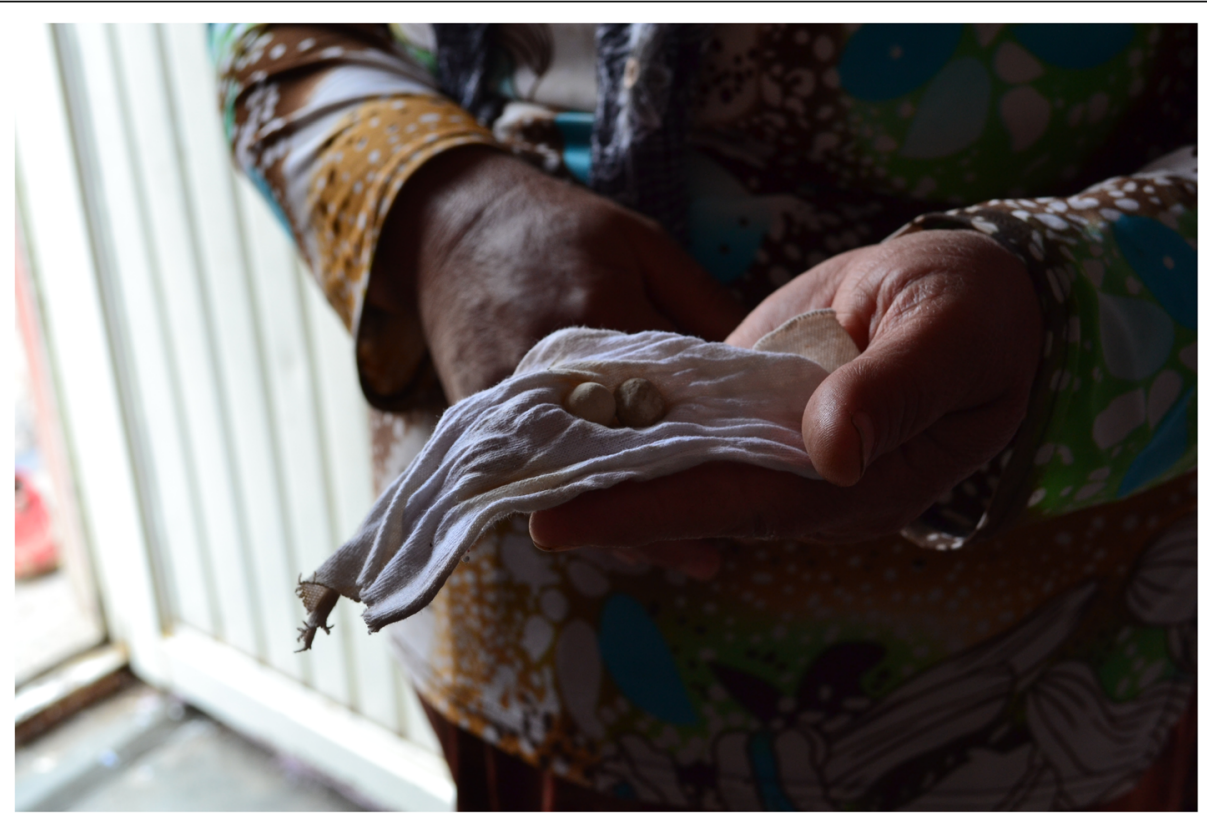

Fig. 10 Berat: Üçkuyular (Feqîra) village, March 13, 2014. Ezidis have to carry berat, the sacred earth pellets brought from the temple of Sheikh Adi in Lalesh which must be kept in a piece of clean cloth. Berat should also be put in the eyes and mouth of the dead. The Ezidis of Batman mention that they have experienced some difficulties about carrying berat abroad, especially on the borders. The lack of information on the pellets often causes confusion among the officials and makes the Ezidis feel culpable and deficient 


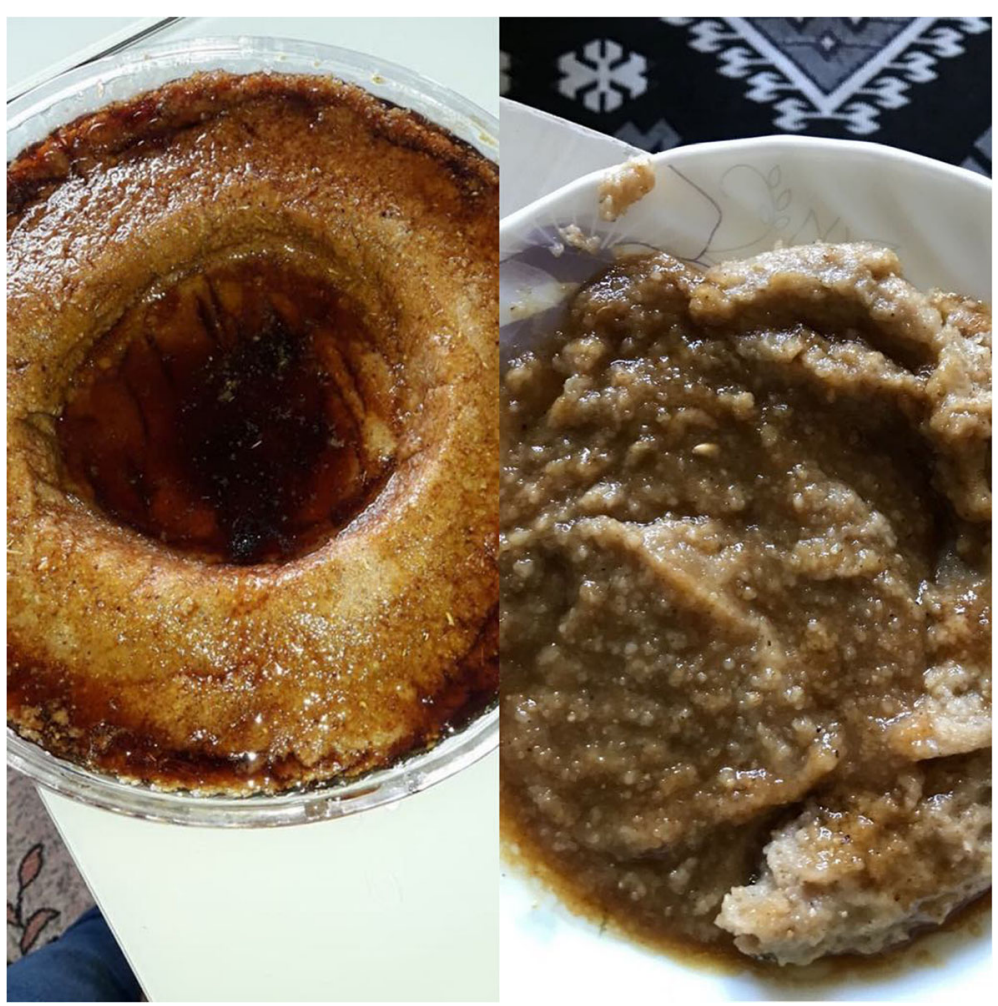

Fig. 11 Pelor: Pelor is prepared with various types of cereals: corn, barley, wheat, lentils, chickpeas, rice and walnuts. The cereals are roasted before grinding in a stone muller. Then, three cups of the cereal and walnuts mixture are boiled with half-liter water for 10 min. After the mixture turns into a mush, it is transferred into a plate. If preferred, it is formed into a round shape with a hollow in the middle. Finally, some molten butter and boiled grape or mulberry juice is poured on the mush. Onbaşı (Şahsim) village, February 19, 2014

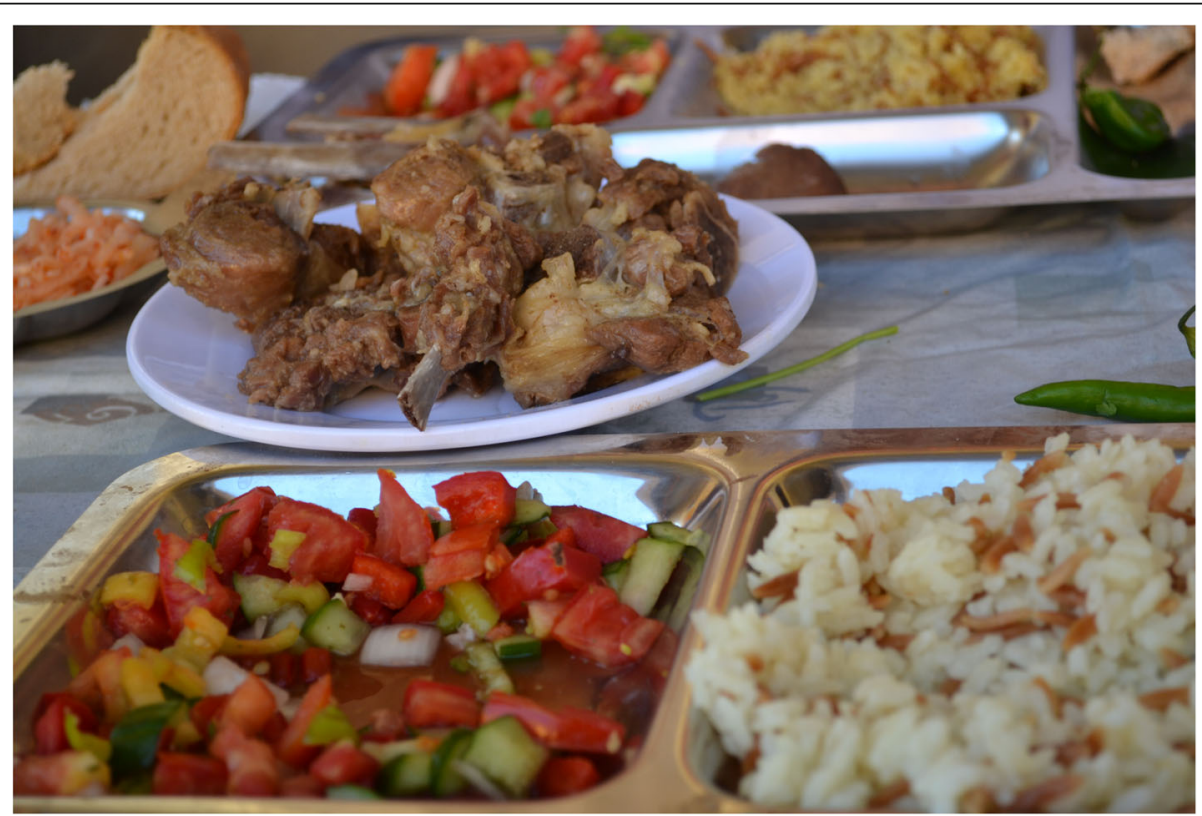

Fig. 12 A Table for the guests: Preferred dishes of meal are generally meat products (preferably lamb, more often chicken, rarely turkey), cereal products (bread, bulgur, or rice), and plants (depending on the season) resembling elevated dishes of Kurdish Muslims of the region. This table including lamb meat, bulgur, rice, and salad was prepared by Ezidis in honor of the guests in Üçkuyular (Feqîra), on July 5, 2013 


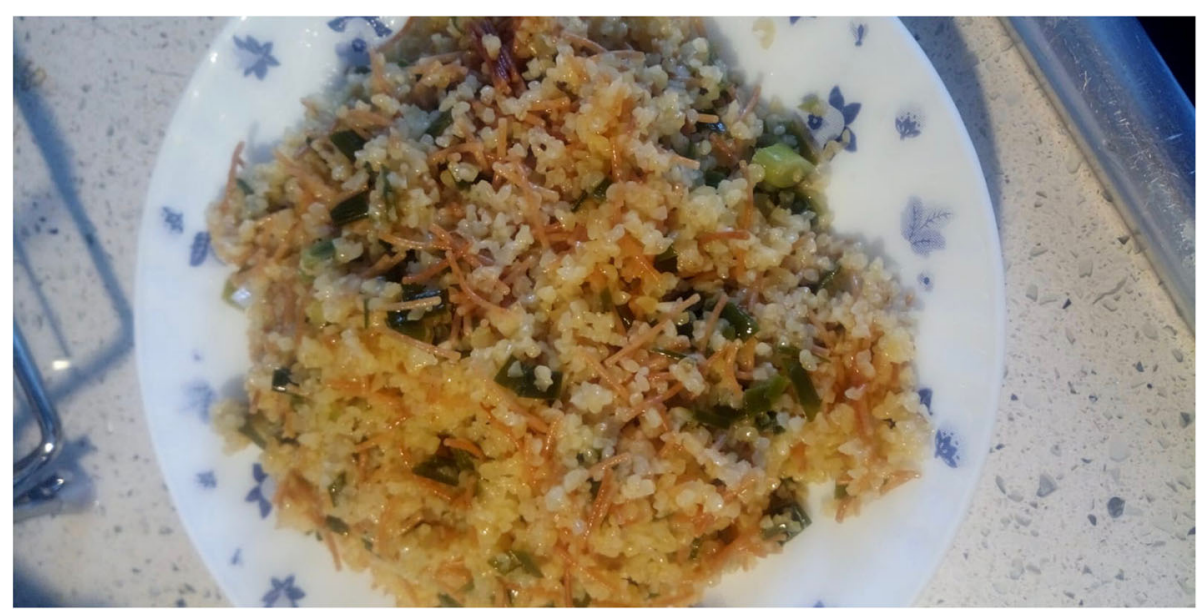

Fig. 13 Sîrim: Sirim, a kind of garlic, is a highly preferred wild plant cooked with bulgur pilaf (sawar) and used for cheese. It is generally ready to add even out of the season since it is stored in the freezer after being gathered and cleaned. Kurukavak (Hamdûna) village, August 8, 2013

individuals' food preferences a part of their belief system with the symbolic meanings that are imposed on foods. In this context, some plants and foods are marked as anomalous by the religion depending on the social organization whereas some become more prominent in terms of ritualistic practices concerning distribution of food and fertility.

As to sum up, it could be suggested that Ezidis unite with the other communities of the region with nutritional methods based on animal products which are common in daily life while they differ in the use of plants and cereals which are operated in ritual practices. As a society where oral communication is still dominant, Ezidis transmit the religious discourse and practices to the next generations via oral traditions. Due to their disparate beliefs and traditions Ezidis are being excluded and marginalized by other societies they live together with. It could be claimed that this dissimilarity uniting Ezidi society in a common sense is also visible through food which is one

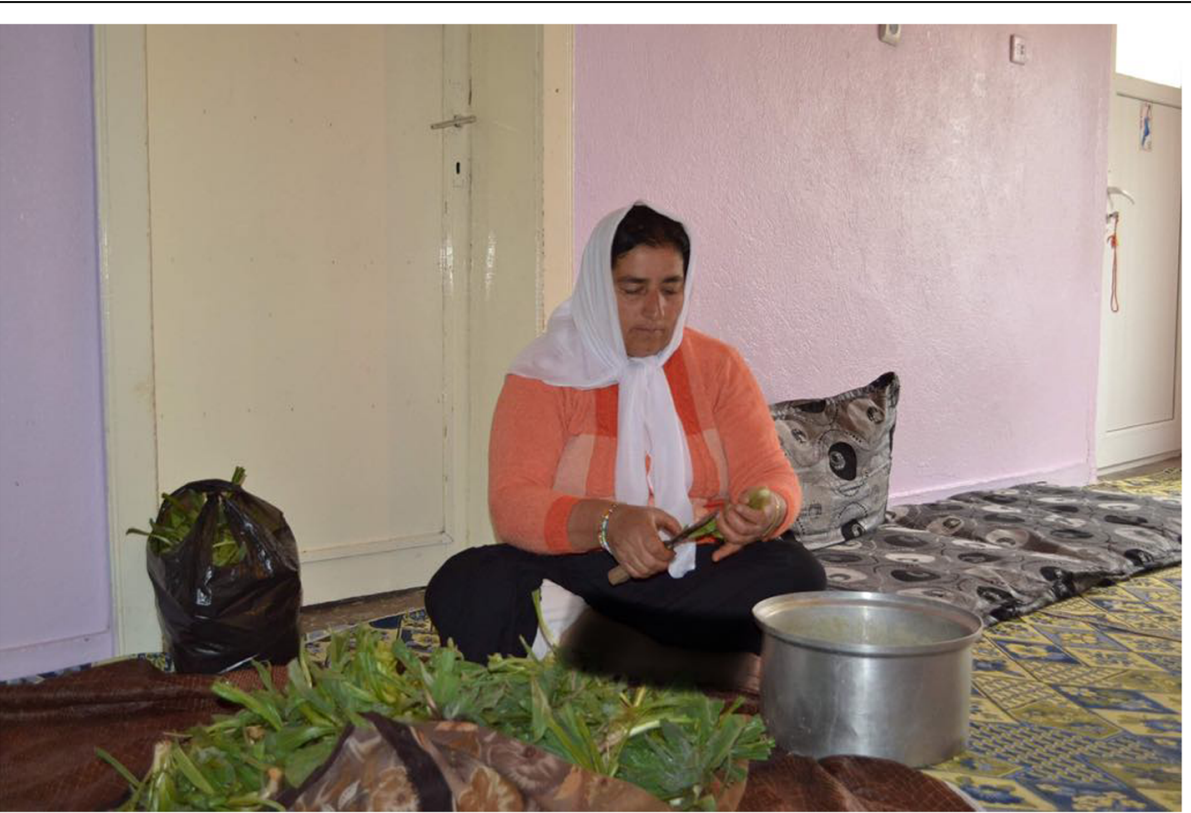

Fig. 14 Gûriz: Ezidi woman cleaning gûriz, a spiny plant in Üçkuyular (Feqîra) village, March 13, 2014. It is hard and painful to pick and chop. It will be drained after boiling in salty water then cooked with some butter and eggs. Generally women are in favor of dishes prepared with wild plants while men prefer meat products 
of the cultural configuration ways of self-expression in Ezidism. The ritualistic uses of plants and foods and the relations of the Ezidis between the others over food are proposed in this study as the basic patterns of identity and behavior that distinguish Ezidi community from others.

\section{Acknowledgements}

The author would like to thank the honest and generous Ezidi informants who opened the doors of their houses in the villages during the fieldwork, whose hearts are in fact not closed to anybody.

\section{Authors' contributions}

The author conceived, wrote, and revised the study, and read and approved the final manuscript.

\section{Author's information}

Berivan Can Emmez conducts her works on culture and ethnicity. Her PhD dissertation entitled "Awazê Tawus: Love and Lament- Ethnographic Approaches on Verbal Culture of Ezidis in Batman (Turkey)" was submitted by the Department of Folklore at Ankara University (Turkey). She is currently working as the Folklore Chair at Batman University (Turkey).

\section{Funding}

Not applicable

\section{Availability of data and materials}

Not applicable

\section{Consent for publication}

\section{Competing interests}

The author declares that she has no competing interests.

Received: 9 August 2019 Accepted: 10 December 2019

Published online: 14 January 2020

\section{References}

1. Adsay F. Yezidi kadınlar, kültürel sınırların edilgen taşıyıcıları. Istanbul: Avesta; 2014. [In Turkish].

2. Altunışık I. Settlements names of Batman province in geographical context. Institute of Social Sciences at Ankara University. Unpublished PhD Dissertation. 2009. [In Turkish]. http://acikarsiv.ankara.edu.tr/browse/5496/.

3. Altuntek S. Native's perspective- ethnography: theory and method. Istanbul: Ütopya; 2009. [In Turkish].

4. Anderson EN. Everyone eats-understanding food and culture. NYU Press: US; 2005.

5. Assmann J. Kültürel bellek- eski yüksek kültürlerde yazi, hatirlama ve politik kimlik. Istanbul: Ayrınti; 2018. [In Turkish].

6. Bates DG. Cultural anthropology in the $21^{\text {st }}$ century. Istanbul: Bilgi Üniversitesi Yayınları; 2009. [In Turkish].

7. Beşirli H. Food, culture and identity. Milli folklor. 2010;87:159-169 [In Turkish]. http://www.millifolklor.com/PdfViewer.aspx?Sayi=87\&Sayfa=156. Accessed 2 Dec2019.

8. Can Emmez B. Awazê Tawus: love and lament-ethnographic approaches on verbal culture of Ezidis in Batman. Institute of Social Sciences at Ankara University. Unpublished PhD Dissertation. 2018. [In Turkish]. https://www. academia.edu/37603615/Awaz\%C3\%AA_Tawus_A\%C5\%9Fk_ve_Yas-_ Batman_Ezidilerinin_S\%C3\%B6zl\%C3\%BC_K\%C3\%BClt\%C3\%BCr\%C3\%BC_\% C3\%9Czerine_Etnografik_Yakla\%C5\%9F\%C4\%B1mlar_Awaz\%C3\%AA_Tawus_ Love_and_Lament_Ethnographic_Approaches_on_Verbal_Culture_of Ezidis_in_Batman_. Accessed 2 Dec2019.

9. Çelik SE, Özyürek M, Altun M, Bektaşoğlu B, Güçlü K, Berker Kl, Özgökçe F, Apak R. Antioxidant capacities of herbal plants used in the manufacture of Van herby cheese: 'otlu peynir'. International journal of food properties. 2008:11/4:747-761. doi: 10.1080/10942910701594210. https://www. sciencedirect.com/science/article/pii/S2352618116000044?via\%3Dihub. .
10. Dietler M. Culinary encounters: food, identity, and colonialism. In: Twiss KC, editor. The archaeology of food and identity. Center for Archaeological Investigations: Illinois; 2006. ISBN 0-88104-091-6.

11. Dursteler ER. Infidel foods: food and identity in early modern Ottoman travel literature, The journal of Ottoman studies. 2012;39-40:143-160. https:// dergipark.org.tr/tr/pub/oa/issue/10939/130757. Accessed 2 Dec 2019.

12. Eliade M. Introduction to the history of religion. Kabalcı: Istanbul; 2009. [In Turkish]

13. Evliya Ç. In: Dankoff R, Kahraman SA, Dağlı Y, editors. Evliyâ Çelebi seyahatnâmesi (Book of travel) V. I. Istanbul: YKY; 2006. [In Turkish].

14. Fischler C. Food, self and identity. Social Science Information. 1988;27:275-93.

15. Geertz C. Interpretation of cultures. Dost: Ankara; 2010.

16. Gökçen A. Ezidiler: kara kitap kara talih. Bilgi Üniversitesi Yayınları: Istanbul; 2014. [In Turkish]

17. Hovsepyan R, Stepanyan-Gandilyan N, Melkumyan H, Harutyunyan L. Food as a marker for economy and part of identity: traditional vegetal food of Yezidis and Kurds in Armenia. Journal of ethnic foods. 2016;3/1:32-41. https://doi.org/10.1016/j.jef.2016.01.003. Accessed 1 Dec 2019.

18. Keskin A. Kurmancî-rojnameya taybetî ya enstîtuya Kurdî ya Parîsê. In: Hejmar 1-40, Havîn 1987-Bihar 2007. Avesta: İstanbul; 2009. [In Kurdish].

19. Kızıl S, Tonçer Ö. Edible plants of south-eastern Anatolia. In: Tıbbi ve aromatik bitkiler sempozyumu bildiriler kitabı. 2014. [In Turkish]. https:// www.researchgate.net/profile/Suleyman Kizil/publication/319482460 Guneydogu_Anadolu_Bolgesinde_Dogadan_Toplanarak_Tuketilen_Bitkiler_ Tibbi_ve_Aromatik_Bitkiler_Sempozyumu/links/5a1fb7b9aca272cbfbc31c51/ Gueneydogu-Anadolu-Boelgesinde-Dogadan-Toplanarak-Tueketilen-BitkilerTibbi-ve-Aromatik-Bitkiler-Sempozyumu.pdf. Accessed 28 March 2018.

20. Kreyenbroek PG. Yezidism- its background, observations and textual traditions. Bilgi Üniversitesi: Istanbul; 2014. [In Turkish]

21. Kreyenbroek PG, Rashow KJ. God and Sheikh Adi are perfect: sacred poems and religious narratives from the Yezidi tradition. Harrasowitz: Wiesbaden; 2005.

22. Layard AH. Ninova ve kalıntıları: Kürdistan'ın Keldani Hıristiyanları, Yezidiler ya da şeytana tapanların ülkesine bir gezi, eski Asur'un töre ve sanatlarının araștırılması. Avesta: Istanbul; 2000. [In Turkish]

23. Ministry of Agriculture and Rural Affairs. List of species to be registered. 2008. https://www.tarimorman.gov.tr/BUGEM/TTSM/Belgeler/Tescil/Kay\% C4\%B1t\%20Alt\%C4\%B1na\%20Al\%C4\%B1nacak\%20T\%C3\%BCr\%20Listesi/ sebze.pdf. Accessed 29 July 2019

24. Munzuroğlu Ö, Karataş F, Gür N. Işgın (Rheum ribes L.) bitkisindeki A, E ve C vitaminleri ile selenyum düzeylerinin araștırılması. Turkish journal of biology. 2000; 24:397-404. [In Turkish]. http://journals.tubitak.gov.tr/biology/issues/ biy-00-24-3/biy-24-3-2-9903-1.pdf. .

25. Okçu D. Yezîdilik ve Yezîdiler. Konya: Tablet; 2007. [In Turkish]

26. Süvari ÇC. Ezidiler: Etnodinsel bir inanç olarak Ezidilik. Ütopya: Ankara; 2013. [In Turkish]

\section{Publisher's Note}

Springer Nature remains neutral with regard to jurisdictional claims in published maps and institutional affiliations.

Ready to submit your research? Choose BMC and benefit from:

- fast, convenient online submission

- thorough peer review by experienced researchers in your field

- rapid publication on acceptance

- support for research data, including large and complex data types

- gold Open Access which fosters wider collaboration and increased citations

- maximum visibility for your research: over $100 \mathrm{M}$ website views per year

At $\mathrm{BMC}$, research is always in progress.

Learn more biomedcentral.com/submissions 